\title{
Status gizi berhubungan dengan kejadian ISPA pada balita di Wilayah Kerja Puskemas Wonosari I Kabupaten Gunungkidul 2014
}

\author{
Nutritional status associated with acute respiratory infections (ARIs) of toddler in Wonosari I Health \\ Centers Working Area of Gunungkidul 2014
}

Wahyu Febrianto ${ }^{1}$, Ircham Mahfoedz², Mulyanti²

\begin{abstract}
Background: The health of children still become a serious concern because child health status reflects the health of the nation. Acute respiratory infections (ARIS) is one of the problem that often occurred in toddler. Healthy life style such as dietary adequacy can support the prevention of the ARIs.

Objectives: To know the association between nutritional status with ARIs incidence of toddler in Wonosari I Health Centers Working Area of Gunungkidul 2014.

Methods: This was an analytical (inductive) method with cross sectional design. The study was conducted in May-June 2014. Samples were selected by used purposive sampling with total sample 43 respondents. Subject were toddler who visit in health centre. Data were taken from secondary datas in Wonosari I Health Centers Working Area of Gunungkidul. Data were analyzed by chi-square formula.

Results: As many as 1 toddler (2,4\%) had severe malnutrition and 7 toddlers $(16,7 \%)$ had undernutrition. While, as many as 10 toddlers (23,8\%) have ARIs. Chi-square analyzed showed that there was association between nutritional status with ARIs incidence $(r=222,41, p=0,000)$.

Conclusions: There was an association between nutritional status with ARIs incidence in Wonosari I Health Centers Working Area of Gunungkidul.
\end{abstract}

KEYWORDS: acute respiratory incidence (ARIS), nutritional status, toddler

\begin{abstract}
ABSTRAK
Latar belakang: Kesehatan anak masih menjadi perhatian serius dikarenakan derajat kesehatan anak mencerminkan derajat kesehatan bangsa. Infeksi saluran pernapasan akut (ISPA) merupakan masalah kesehatan yang sering terjadi pada anak. Pola hidup sehat pada anak mendukung pencegahan penyakit ISPA, salah satunya dengan terpenuhinya nutrisi.

Tujuan: Mengetahui hubungan antara status gizi dengan kejadian ISPA pada balita di Wilayah Puskesmas Wonosari I Kabupaten Gunungkidul

Metode: Penelitian ini menggunakan metode penelitian analitik (induktif) dengan pendekatan cross sectional. Penelitian dilaksanakan pada bulan Mei-Juni 2014. Lokasi penelitian di Wilayah Kerja Puskesmas Wonosari I Kabupaten Gunungkidul. Subjek adalah balita yang berkunjung ke Puskesmas Wonosari I Kabupaten Gunungkidul. Sampel penelitian diambil menggunakan teknik purposive sampling berjumlah 43 responden. Data yang digunakan adalah data sekunder yang didapatkan dari data Puskesmas Wonosari I.

Hasil: Sebanyak 1 balita (2,4\%) mengalami gizi buruk dan 7 balita (16,7\%) dengan gizi kurang. Sebanyak 10 balita $(23,8 \%)$ mengalami ISPA. Hasil analisis chi-square menunjukkan adanya hubungan antara status gizi dengan kejadian ISPA $(r=22,241, p=0,000)$.

Kesimpulan: Ada hubungan antara status gizi dengan kejadian ISPA pada balita di Wilayah Puskesmas Wonosari I Kabupaten Gunungkidul.
\end{abstract}

KATA KUNCI: kejadian ISPA, status gizi, balita

\footnotetext{
${ }_{1}$ Program StudiKeperawatan, STIKES Alma Ata Yogyakarta, Jl. Ringroad Barat Daya 1, Yogyakarta,e-mail: wahyublack1992@gmail.com

${ }^{2}$ Program StudiKeperawatan, STIKES Alma Ata Yogyakarta, Jl. Ringroad Barat Daya 1, Yogyakarta
} 


\section{PENDAHULUAN}

Kesehatan anak masih menjadi perhatian serius di antara masalah kesehatan yang lain karena derajat kesehatan anak mencerminkan derajat kesehatan bangsa. Anak merupakan generasi penerus yang mempunyai kemampuan untuk dikembangkan dalam meneruskan pembangunan bangsa. Masalah kesehatan anak adalah prioritas dalam perencanaan dan pembangunan bangsa (1). Masalah kesehatan anak yang umum terjadi meliputi beberapa penyakit di antaranya adalah infeksi saluran pernafasan akut (ISPA), infeksi radang tenggorokan, rhinitis alergi, infeksi telinga tengah,cacar air, diare, dan masalah kulit.

Angka kematian balita di negara berkembang masih cukup tinggi. Menurut Lembaga Kesehatan Dunia/WHO (World Health Organization) menunjukkan di negara berkembang sebanyak 4 juta dari 15 juta kematian anak di bawah 5 tahun disebabkan oleh ISPA (2). Berdasarkan hasil riset kesehatan dasar (Riskesdas) disebutkan sebanyak $22,5 \%$ atau 16 provinsi di Indonesia mempunyai prevalensi ISPA berkisar $25,5 \%$ (rentang $17,5 \%-41,4 \%$ ) dan pneumonia sebanyak 2,1\% (rentang 0,8\%-5,6\%) (3).

Kejadian ISPA yang masih tinggi di Indonesia dipengaruhi oleh berbagai faktor, antara lain faktor lingkungan dan host. Faktor lingkungan yang mempengaruhi terjadinya ISPA pada balita di antaranya adalah kualitas udara yang kurang baik yang disebabkan oleh asap rokok, asap dapur, dan ventilasi rumah, sedangkan faktor host meliputi beberapa hal, diantaranya adalah status umur, status gizi, riwayat pemberian $\mathrm{ASI}$, berat bayi lahir rendah (BBLR), dan imunisasi (4). Balita dengan imunisasi tidak lengkap, gizi kurang, dan BBLR akan lebih mudah terserang penyakit karena mekanisme pertahanan tubuh (imunitas) yang belum lengkap (5). Balita yang sering mengalami ISPA akan memiliki status gizi yang rendah disebabkan oleh energi yang seharusnya digunakan untuk proses pertumbuhan digunakan untuk proses penyembuhan, begitu pula sebaliknya seorang balita akan lebih mudah terkena ISPA jika status gizi rendah/ kurang karena tubuh (6).

Daerah Istimewa Yogyakarta merupakan wilayah yang selalu menempati sepuluh besar penderita ISPA (bronkitis, asma, dan pneumonia) dalam beberapa tahun terakhir. Total kunjungan pasien ISPA ke puskesmas mencapai 70.942 pasien, persentase penyakit ISPA di setiap kabupaten/ kota mencapai $31 \%-39 \%$ dari seluruh penyakit (7). Penekanan angka kematian balita merupakan sebuah program Pemerintah Indonesia dalam pencapaian target millennium development goals (MDGs) dalam bidang kesehatan. ISPA merupakan salah satu penyebab kematian terbesar pada balita. Apabila program tersebut dapat menurunkan 2/3 kematian balita dalam rentang waktu 19902015, maka hal tersebut akan berdampak pada pencapaian MDGs (2).

Kabupaten Gunungkidul merupakan daerah dengan epidemik ISPA yang cukup tinggi, yaitu sekitar $22 \%$. Daerah dengan prevalensi ISPA tertinggi memiliki prevalensi pneumonia yang tinggi juga. Hal ini disebabkan ISPA yang tidak ditangani dengan baik akan berkembang menjadi pneumonia. Prevalensi pneumonia di Gunungkidul mencapai $2,7 \%$. Angka tersebut lebih tinggi dari prevalensi pneumonia rata-rata di Provinsi DIY yang hanya sebesar 1,8\% (7). Berdasarkan studi pendahuluan yang dilakukan oleh Puskesmas Wonosari I Kabupaten Gunungkidul, angka kunjungan tertinggi adalah ISPA/common cold sebesar 3,958. Di antaranya dari jumlah tersebut, 576 pengunjung adalah balita atau sekitar $14,55 \%$.

Berdasarkan data dari Riskesdas tahun 2013, diketahui bahwa prevalensi gizi buruk dan gizi kurang masing-masing pada tahun 2013 sebesar $5,7 \%$ dan $13,9 \%$ (8). Data menurut Profil Kesehatan DIY tahun 2012 menunjukkan bahwa prevalensi gizi kurang dan gizi buruk masing-masing $8,45 \%$ dan $0,56 \%$ (9). Data dari puskesmas Wonosari I tahun 2013 menunjukkan prevalensi gizi kurang sebesar $8,15 \%$ (10). Hal tersebut menunjukkan bahwa angka prevalensi gizi kurang di Puskesmas Wonosari I masih tinggi $(8,15 \%)$ karena mendekati angka prevalensi gizi kurang di DIY $(8,45 \%)$.

\section{BAHAN DAN METODE}

Jenis penelitian ini menggunakan induktif (inferensial) dengan pendekatan cross sectional. 
Tujuan dari penelitian ini adalah untuk mengetahui hubungan antara status gizi dengan kejadian ISPA pada balita di Puskesmas Wonosari I. Penelitian dilaksanakan pada bulan Mei hingga Juni 2014. Variabel bebas adalah status gizi dan variabel terikat adalah kejadian ISPA. Populasi dalam penelitian ini adalah balita sakit yang berkunjung di Puskesmas Wonosari I sebanyak 144 balita. Sampel dalam penelitian ini sebanyak 43 balita. yang diperoleh dengan teknik purposive sampling. Kriteria inklusi adalah balita yang berkunjung di Puskesmas Wonosari I, balita tidak cacat fisik maupun mental, sedangkan kriteria eksklusi meliputi balita yang tidak sadarkan diri, balita yang bukan domisili di wilayah kerja puskesmas.

Untuk mengetahui hubungan status gizi dengan kejadian ISPA pada balita adalah digunakan data sekunder yang terdapat pada buku kartu menuju sehat (KMS) dan juga dari data kesehatan ibu dan anak (KIA) puskesmas yang kemudian dihitung dan disesuaikan dengan tabel baku nilai rujukan status gizi untuk mengkategorian status balita ke dalam gizi buruk, kurang, baik, atau lebih. Analisis data mengunakan uji univariat dan bivariat.

$$
(1+x)^{n}=1+\frac{n x}{1 !}+\frac{n(n-1) x^{2}}{2 !}+\cdots
$$

\section{HASIL}

Sampel dalam penelitian ini sebanyak 42 balita yang berkunjung ke Puskesmas Wonosari. Karakteristik responden dalam penelitian ini dapat dilihat pada Tabel 1.
Tabel 1. Distribusi frekuensi responden sampel penelitian

\begin{tabular}{lcc}
\hline \multicolumn{1}{c}{ Karakteristik } & Frekuensi & Persentase (\%) \\
\hline Jenis kelamin & & \\
Laki-laki & 25 & 59,5 \\
Perempuan & 17 & 40,5 \\
Total & 42 & 100 \\
Kejadian ISPA & & \\
ISPA & 10 & 23,8 \\
Tidak ISPA & 32 & 76,2 \\
Total & 42 & 100 \\
Status gizi & & \\
Gizi buruk & 1 & 2,4 \\
Gizi kurang & 7 & 16,7 \\
Gizi baik & 33 & 78,6 \\
$\quad$ Gizi lebih & 1 & 2,4 \\
Total & 42 & 100 \\
\hline
\end{tabular}

Berdasarkan Tabel 1 didapatkan karakteristik sampel penelitian ini berjenis kelamin laki-laki sebanyak 25 balita $(59,5 \%)$, tidak mengalami ISPA sebanyak 32 balita $(76,2 \%)$ dan status gizi baik sebanyak 33 balita $(78,6 \%)$.

Berdasarkan tabulasi silang pada Tabel 2, diketahui sampel dengan status gizi baik dan tidak ISPA sebanyak 30 balita $(71,4 \%)$, sedangkan dengan status gizi baik dan ISPA sebanyak 3 balita $(7,1 \%)$.

Berdasarkan hasil analisis menggunakan uji statistik nonparametric correlation dengan menggunakan chi-square didapatkan nilai $p=0,000$ yang menunjukkan terdapat hubungan negatif antara status gizi dengan kejadian ISPA pada balita di Wilayah Kerja Puskesmas Wonosari Gunung Kidul. Hasil nilai dari koefiensi kontinensi 22,241 yang berarti bahwa hubungan antara status gizi dengan kejadian ISPA dalam kategori sedang.

Tabel 2. Tabulasi silang dan uji chi-square antara kejadian ISPA dengan status gizi

\begin{tabular}{lcccccccc}
\hline \multirow{2}{*}{$\begin{array}{c}\text { Penilaian } \\
\text { status gizi }\end{array}$} & \multicolumn{9}{c}{ Tidak ISPA } & \multicolumn{2}{c}{ ISPA } & \multicolumn{2}{c}{ Total } & \multirow{2}{*}{$x^{2}$} & \multirow{2}{*}{$\mathbf{p}$} \\
\cline { 2 - 7 } & $\mathbf{f}$ & $\%$ & $\mathbf{f}$ & $\%$ & $\mathbf{f}$ & $\%$ & & \\
\hline Buruk & 0 & 0 & 1 & 2,4 & 1 & 2,4 & 22,241 & 0,000 \\
Kurang & 1 & 2,4 & 6 & 14,3 & 7 & 16,7 & & \\
Baik & 30 & 71,4 & 3 & 7,1 & 33 & 78,5 & & \\
Lebih & 1 & 2,4 & 0 & 0 & 1 & 2,4 & & \\
Total & 32 & 76,2 & 10 & 23.8 & 42 & 100 & & \\
\hline
\end{tabular}




\section{BAHASAN}

\section{Kejadian ISPA}

Berdasarkan Tabel 1 diketahui sebanyak 10 balita $(23,8 \%)$ mengalami ISPA. Jumlah ini sesuai dengan hasil Riskesdas yang menjelaskan bahwa prevalensi kejadian ISPA di Indonesia berada pada rentang 17,5\%-41,4\% (3). Jumlah kejadian ISPA di Wilayah Kerja Puskesmas Wonosari I Gunung Kidul masih tergolong cukup dibandingkan dengan angka kejadian ISPA di wilayah Yogyakarta.

\section{Penilaian status gizi}

Tabel 1 menunjukkan bahwa mayoritas balita yang berkunjung ke Puskesmas Wonosari I memiliki status gizi baik yaitu sebanyak 33 balita $(78,5 \%), 7$ balita dengan gizi kurang $(16,7 \%)$, balita dengan gizi lebih $(2,4 \%)$, dan 1 balita dengan gizi buruk $(2,4 \%)$. Hal tersebut menunjukkan bahwa pengetahuan dan kesadaran akan pentingnya pemberian asupan gizi tergolong cukup.

\section{Hubungan antara status gizi dengan kejadian ISPA}

Tabel 2 diketahui bahwa ada hubungan negatif antara status gizi dengan kejadian ISPA pada balita di Wilayah Kerja Puskesmas Wonosari I Kabupaten Gunungkidul. Hasil ini menunjukkan bahwa semakin baik status gizi balita, maka semakin kecil risiko balita terkena ISPA. Hasil penelitian ini didukung oleh hasil penelitian lain yang menjelaskan bahwa balita dengan status gizi kurang memiliki risiko menderita pneumonia lebih besar (11). Status gizi yang rendah akan mempengaruhi frekuensi terjadinya ISPA pada balita (6).

Frekuensi kejadian ISPA pada balita dengan status gizi kurang lebih tinggi dibandingkan dengan anak yang memiliki status gizi baik. Hal ini disebabkan balita yang mempunyai status gizi baik akan mempunyai daya tahan (antibodi) yang lebih, sehingga dapat mencegah atau terhindar dari penyakit seperti ISPA (12).

Berdasar hasil penelitian pada Tabel 2, sebanyak 32 balita $(76,2 \%)$ tidak mengalami ISPA di Wilayah Kerja Puskesmas Wonosari I Kabupaten Gunungkidul. Angka kejadian ISPA ini cukup rendah disebabkan program perbaikan gizi pada balita terlaksana dengan baik, sehingga balita dengan gizi baik akan mengurangi risiko terjadinya penyakit ISPA. Status gizi balita mempengaruhi kejadian ISPA. Balita dengan status gizi tidak baik akan berisiko 2,7 kali mengalami ISPA dibandingkan dengan balita yang memiliki status gizi baik (13). Balita dengan gizi buruk memiliki risiko mengalami infeksi disebabkan antibodi dari balita yang belum sempurna(14).

Status gizi yang baik pada balita sangat diperlukan karena dapat terhindar dari penyakitpenyakit seperti ISPA. Status gizi baik dapat dicapai jika asupan gizi balita sesuai dengan kebutuhannya. Status gizi baik terbukti mempengaruhi pertumbuhan fisik, perkembangan mental dan intelektual, meningkatkan produktivitas, serta menurunkan angka kesakitan dan kematian (15).

Hasil penelitian yang dilakukan oleh Fonseca pada tahun 1996 menunjukkan bahwa status gizi kurang menempati urutan pertama terjadinya pneumonia pada balita. Selain itu penelitian yang dilakukan di Solopur India juga menunjukkan bahwa sebanyak 160 anak di bawah 5 tahun hanya 44 (27,5\%) yang mempunyai status gizi normal sisanya dengan status gizi kurang. Hasil uji statistik menunjukkan risiko 5,17 kali lebih buruk terjadi ISPA pada balita yang mempunyai status gizi kurang dibandingkan dengan yang mempunyai status gizi baik (16).

Gizi merupakan salah satu penentu kualitas sumber daya manusia. Kejadian malnutrisi akan menurunkan imuntas selular, kelenjar timus dan tonsil menjadi atrofik dan jumlah T-limfosit berkurang, sehingga tubuh akan menjadi lebih rentan terhadap terjadinya penyakit atau infeksi. Selain itu, kejadian malnutrisi akan mempengaruhi saluran pernafasan dalam melindungi dari agen penyakit. Saluran nafas yang normal secara fisiologis dapat menghalau agen penyakit yang masuk ke dalam tubuh melalui berbagai mekanisme, misalnya batuk dan meningkatnya jumlah cairan mukosa, namun pada anak yang mengalami malnutrisi/status gizi kurang baik proses fisiologis itu tidak dapat berjalan dengan baik, sehingga agen penyakit yang masuk tidak dapat dihalau keluar dan akan terakumulasi dalam saluran nafas dan di paru-paru (17). 
Hasil penelitian ini juga menunjukkan bahwa sampel dengan status gizi baik tetap terkena ISPA. Hal ini disebabkan penyebab ISPA bukan hanya dari status gizi saja, tetapi juga dipengaruhi oleh faktor lain, seperti usia, pemberian ASI, terpapar atau tidaknya dengan polusi, status sosial ekonomi, BBLR, dan lain-lain. Balita dengan status gizi yang baik tetap bisa mengalami ISPA karena faktor lingkungan, misalnya anggota keluarga yang lain mengalami ISPA, sehingga tertular atau mungkin dipengaruhi faktor lingkungan yang lain. Berdasarkan hasil tersebut, dapat disimpulkan bahwa status gizi memegang peranan dalam kesehatan. Jika balita mempunyai status gizi yang kurang, maka akan lebih mudah menyebabkan kuman masuk dan tubuh tidak mampu melawan sehingga akan terjadi ISPA.

\section{KESIMPULAN DAN SARAN}

Mayoritas balita yang berkunjung ke Puskesmas Wonosari I adalah berjenis kelamin laki-laki, yaitu sebanyak 25 balita $(59,5 \%)$, sedangkan balita berjenis kelamin perempuan sebanyak 17 balita (40,5\%). Sebanyak 10 balita $(23,8 \%)$ mengalami ISPA. Terdapat hubungan yang ada hubungan antara status gizi dengan kejadian ISPA pada balita di Wilayah Puskesmas Wonosari I Kabupaten Gunungkidul. Saran yang dapat diberikan yaitu: bagi profesi keperawatan diharapkan dapat menerapkan program pemenuhan gizi dengan baik untuk mengurangi kejadian gizi buruk yang dapat menyebabkan tingginya angka kematian balita. Bagi puskesmas, diharap selalu meningkatkan pelayanan untuk mempertahankan status gizi, baik pada balita melalui pengembangan program puskesmas, sehingga balita tidak mudah terserang penyakit. Bagi masyarakat, sebaiknya turut serta dalam menurunkan kejadian ISPA pada balita dengan memperbaiki atau meningkatkan dan memenuhi status gizi pada balita. Bagi peneliti lain diharapkan dapat dilakukan penelitian lebih lanjut mengenai faktor lain yang dapat meningkatkan risiko terjadinya ISPA yaitu berat badan lahir, cakupan imunisasi, status ekonomi dan lingkungan tempat tinggal dengan metode cohort atau case-control.

\section{RUJUKAN}

1. Hidayat A. Ilmu kesehatan anak untuk pendidikan kebidanan. Jakarta: Salemba Medika; 2008.

2. Indrayana S. Perbedaan kejadian ISPA menurut karakteristik balita di Puskesmas Semanul. STIKES Alma Ata Yogyakarta; 2011.

3. Departemen Kesehatan Repuplik Indonesia. Riset Kesehatan Dasar 2007. Jakarta: Badan Penelitian dan Pengembangan Kesehatan Rl; 2007.

4. Trisnawati, Juwarni. Hubungan perilaku merokok orang tua dengan kejadian ISPA pada balita di Wilayah Kerja Puskesmas Rembang. Akademi Kebidanan YLPP; 2012.

5. Layuk R, Narsi N, Wahidudin. Faktor yang berhubungan dengan kejadian ISPA pada balita di Lembang Batu Sura. Universitas Hassanudin; 2012.

6. Elyana M, Aryu C. Hubungan frekuensi ISPA dengan status gizi balita [Internet]. 2008. Available from: file:///C:/Users/Alma Ata/ Downloads/4859-10582-1-SM (3).pdf

7. Yogyakarta DKDI. Profil kesehatan Daerah Istimewa Yogyakarta. Yogyakarta: Depkes DIY; 2008.

8. Kementerian Kesehatan Republik Indonesia. Riset kesehatan dasar 2013. Jakarta: Badan Penelitian dan Pengembangan Kesehatan Kemenkes Rl; 2013.

9. Yogyakarta DKDI. Profil kesehatan DIY tahun 2013. Yogyakarta: Dinas Kesehatan Provinsi DIY; 2013.

10. Program Gizi Puskesmas Wonosari I. Situasi derajat kesehatan Puskesmas Wonosari I [Internet]. Gunungkidul; 2014 [cited 2014 Mar 10]. Available from: http://uptpuskesmaswonosari1. blogspot.co.id/2014/06/situasi-derajatkesehatan-puskesmas.html

11. Setiawan R, Ida, Budi. Hubungan status gizi dengan kejadian pneumonia pada balita di Wilayah Kerja Puskesmas Palasari Kecamatan Cianter Kabupaten Subang tahun2010. Poltekkes Kemenkes Bandung; 2010.

12. Dwijayanthi L. Ilmu gizi menjadi sangat mudah. Jakarta: Penerbit Buku Kedokteran EGC; 2008. 
13. Windarti. Hubungan pemberian ASI eksklusif dengan kejadian ISPA pada bayi. Universitas Udayana Bali; 2009.

14. Lakoro $F$. Hubungan status gizi dan imunisasi terhadap kejadian ISPA di Wilayah Kerja Puskesmas Bonepantai Kabupaten Bone Bolango. J Kesehat. 2013;1(1).

15. Musrifu A. Hubungan tingkat pengetahuan ibu tentang pola makan dengan status gizi Balita di Posyandu Desa Batuetno
Banguntapan Bantul DIY. STIKES Alma Ata Yogyakarta; 2013.

16. Prasad D, Chandrashekar H, Madhavi VR. Study of Risk Factors of acute respiratory infection (ARI) in Underfires Solapur. Natl J Community Med. 2010;1(1):64-7.

17. Hadiana S. Hubungan status gizi terhadap terjadinya infeksi saluran nafas akut (ISPA) pada balita di Puskesmas Pajang Surakarta [Internet]. 2013 [cited 2014 Jul 5]. Available from: http://eprints. ums.ac.id/22566/9/NASKAH_PUBLIKASI.pdf 